Ninth Scientific Meeting-Fourth Scomtish Meeting

Edinburgh University New Buildings, December $12 \mathrm{Th}, 1942$

\title{
THE INFLUENCE OF DIET ON PREGNANCY AND LACTATION IN THE MOTHER, THE GROWTH AND VIABILITY OF THE FOETUS, AND POST-NATAL DEVELOPMENT
}

\author{
PART 1. PREGNANCY \\ Chairman, Professor R. C. Garky
}

Professor R. C. Garry (University College, Dundee, University of St. Andrews): Pregnancy is a natural process and should continue so to be regarded both by the medical profession and by the lay public. Nevertheless it is probably true that pregnancy is a strain on the maternal organism, metabolically as well as physically. The factor of safety with which the human body is endowed in all its activities may be exceeded. Thus, it is possible that deficiencies, latent under conditions of normal life, may become patent during pregnancy. Moreover, we should not close our eyes to the fact that our social system is such that this period of inevitable, natural, physiological strain is too often accompanied by financial stringency. The increased demands of pregnancy and of motherhood are not met by increased provision of help in the home.

Although much attention has been paid to the grosser catastrophes and mechanical difficulties of pregnancy and of labour we are still woefully ignorant of the more subtle metabolic changes associated with the nutrition of the unborn child. We have barely begun to understand the role of the placenta in conveying food materials and oxygen to, and removing waste from, the foetus. In addition, the placenta seems to act as a temporary maternal ductless gland. Thus, true appreciation of the importance of proximate principles and of accessory food factors must wait on greater knowledge of placental and foetal metabolism.

All we can hope to do at present is to record observations, to rely on frank empiricism. From studies of experimental and of farm animals, and from the experiences of mankind, we are accumulating data concerning nutrition with reference to successful pregnancy. But, until such knowledge becomes truly scientific, we shall fail to resolve our uncertainties, dispose of controversy, check the excesses of the less critical enthusiasts and gain the wholehearted support of the more sceptical among us. We are at present unable to assess accurately the causes of wastage of young life, both in lower animals and in man; during pregnancy and in the neo-natal period. Statistics show that such wastage is serious. It is our task to try to find the part played by proper nutrition in ensuring normal pregnancy and viable healthy offspring. 


\title{
The Role of the Placenta in Foetal Nutrition
}

\author{
Professor A. St. G. Huggett (St. Mary's Hospital Medical School, \\ Praed Street, London, W.2)
}

Comparative Morphology. The yolk sac placenta is, in most animals, a transient organ, and even where it persists (rodents) plays a subsidiary part to the allantoic or the chorionic placentae which provide the main nutritional supplies of the foetus.

The allantoic placenta consists, in its simplest form, of eight tissues, four maternal and four foetal:

(1) Blood

\section{Maternal}

(2) Vascular endothelium

(3) Decidual stroma, containing uterine glands

(4) Decidual epithelium.

Foetal

(1) Chorion or trophoblast (epithelium or syncytium)

(2) Connective tissue of the villi (mesoblast)

(3) Vascular endothelium

(4) Blood.

This simple type is seen in the horse and pig. The foetal layers are apposed to the maternal layers. At birth separation is easy, practically no maternal tissue is lost, and the maternal placenta is absorbed.

As the scale is ascended, the foetal placenta develops chorionic villi which penetrate into the decidua, eroding it in various degrees in the different types, till in the extreme case the chorion is bather in maternal blood. This process appears to be aided by maternal endarteritis obliterans, causing anoxia, oedema and infarction. In this way we get the four types (Grosser, 1925): epithelio-chorial in the pig, syndesmochorial in the cow, endothelio-chorial in the dog, haemo-chorial in man. Only in the last stage of guineapig placentation does the haemo-chorial progress to foetal degeneration giving a haemo-endothelial placenta with one layer between the two circulating bloods (Mossman, 1926). The types are shown diagrammatically in Figure $\mathbf{I}$.

Not only do we get this comparative anatomical structure at full term in the different types of placenta, but we also find the highest types progressing through these changes in their development. Ontogeny repeats phylogeny. Even the human placenta shows an epithelio-chorial structure in its earliest development. The degenerative change in late pregnancy is physiological and normal. It may be so pronounced that there may be, in some species (man and goat), active loss of placental weight in late pregnancy. In other animals growth only slows down (rat).

The second important point is that the placenta shows differences in regard to transfusion of substanoes as the different layers exist or disappear, as there are six layers to traverse or merely four, or even only one.

The Sources of Food for the Embryo. There are three sources: the secretion of the uterine glands, the autolysed maternal tissues, and the foods dissolved in the maternal blood. In the herbivora the first is of voL. 1,1944$]$ 
preponderating importance; in the carnivora the autolysed decidua and blood appear to supply most food, while, in the primates, those supplies are rapidly replaced by the food carried in the maternal blood stream. This, of course, is a very superior type of food supply, since it is capable

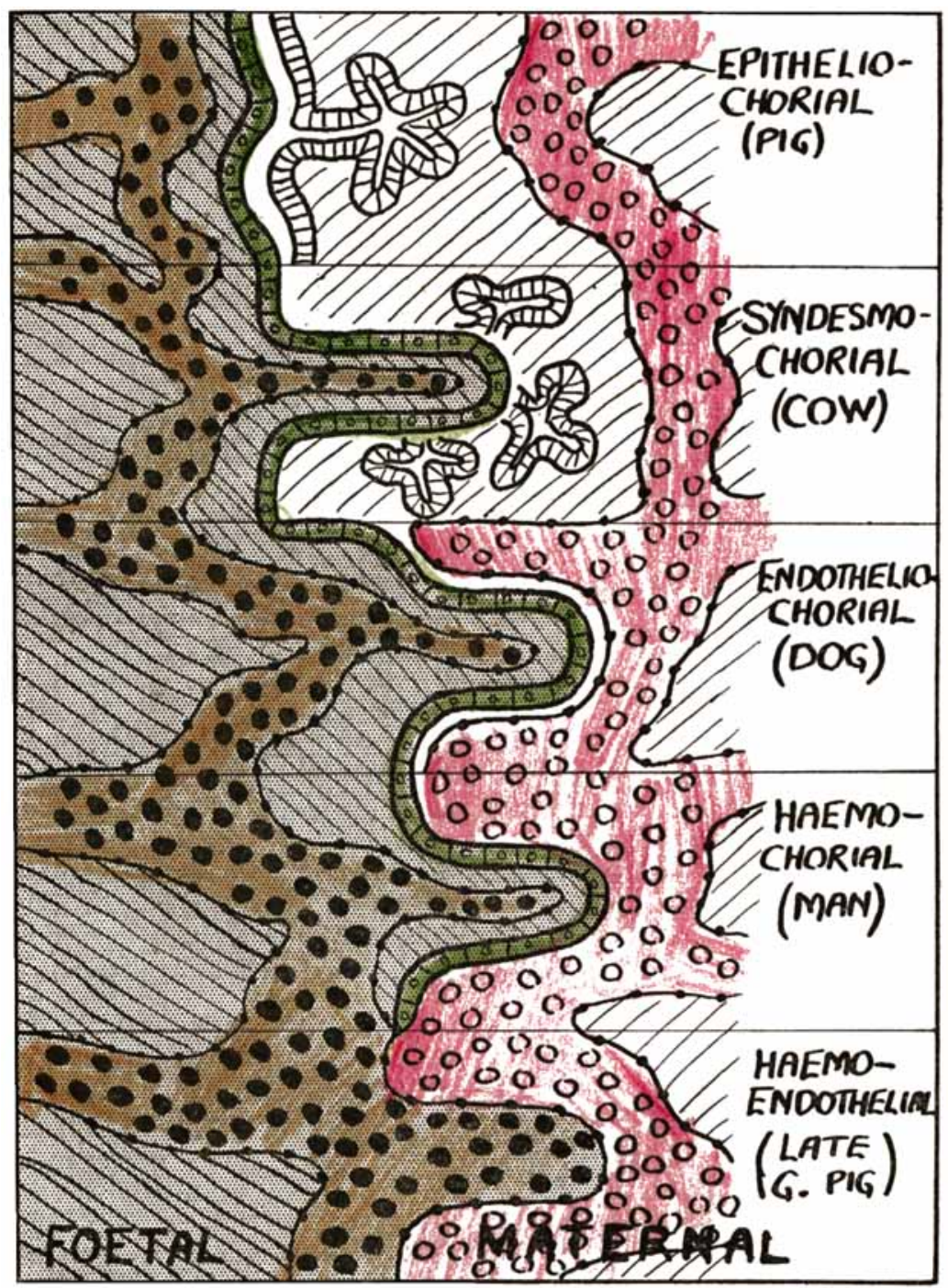

Figure 1. Types of Placenta (Diagrammatic).

of rapid replenishment from moment to moment, independent of local placental stocks or glandular activity, and best calculated to support rapid growth and metabolic changes, such as the foetus exhibits. For 
the first time the embryo is, in regard to food supplies, treated by its mother as generously as any of her own organs.

Transfusion of Crystalloids. If we now examine the relative concentrations of the different foodstuffs, we see that a gradient sometimes exists, that one substance may have a higher concentration in the foetal blood, a second may be higher in the maternal, a third equal in the two bloods. Table 1, after Needham (1931), summarizes the relative concentrations. Occasionally, as in the case of sugar, the gradient is from mother to foetus in man, and from foetus to mother in the cow and pig. In these animals there are, between the two bloods, five and six layers, all full blooded and active consumers of oxygen, and persisting to full term. This suggests that, in the ungulates, the epithelium and stroma of the decidua actively force glucose across.

\section{TABLE 1}

Relative Concentratrons in Maternal and Foetal Bloods (after Needham, 1931)

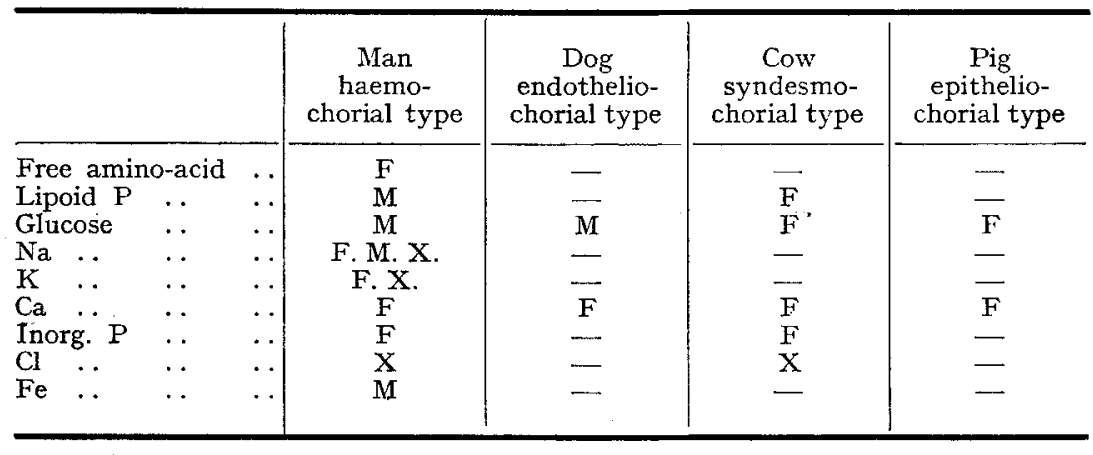

F: foetal higher

M: maternal higher

$\mathrm{X}$ : equal

In the case of water there are certain salient facts. First, the foetus is growing extremely fast, and water is passing to it throughout pregnancy. Second, the maternal blood pressure almost invariably exceeds the foetal. It should be noted, however, that so far as one knows, no measurement has been made of the vascular pressures in the maternal blood sinuses of the decidua, or of the capillary pressure in the foetal chorionic villi. Third, the osmotic pressure of the foetal blood either exceeds, or is equal to, the osmotic pressure of the maternal blood, but is never less than that of the mother's blood. There is no information available as to the source of energy for this concentration of solutes on the foetal side, though there is plenty of opportunity for surmise and experiment.

The actual passage of gases between the foetal and maternal bloods is apparently by diffusion. Positive pressure gradients exist for both oxygen and carbon dioxide, and it is possible to reverse the flow of carbon dioxide in the goat by reversing the carbon dioxide gradient by asphyxiating the mother (Huggett, 1927).

Transfusion of Golloids. The chorionic villi absorb colloids, particles, cell debris and other materials of high molecular weight, apparently without the colloids being first hydrolysed to diffusible substances.

vor. 1, 1944] 
In addition, the placenta accumulates or stores certain foodstuffs, in fact it seems to possess a hepatic storage function.

Proteins. The amino-acid and non-protein nitrogen contents of the foetal blood invariably exceed those of the maternal and so the gradient opposes diffusion (Slemons, 1919; Needham, 1931). The gradient is preserved on a higher level, when the maternal blood amino-acid content rises. It has been known for some time that proteins can pass across, apparently without hydrolysis to simplest products. Antitoxins can traverse the rabbit's placenta in the latter part of pregnancy, and the quantity rises rapidly after the 25th day, when the maternal placenta is degenerating (Rodolfo, 1934). The ungulate epithelio-chorial placenta is impermeable to antitoxin (Mason, Dalling and Gordon, 1930), but the guineapig's haemo-chorial placenta is permeable (Ratner, Jackson and Gruehl, 1927). It has recently been shown in erythroblastosis foetalis that the human placenta is permeable to the $\mathrm{Rh}$ antigen which goes from foetus to mother, and the antibody going back smashes the foetal red cells and bone marrow (Levine, Burnham, Katzin and Vogel, 1941). In the rat, insulin at first fails to traverse the placenta, but at full term, when the placenta becomes haemo-chorial, the increased permeability is shown by the passage of insulin (Corey, 1932). The increased permeability which accompanies degenerative changes in man is shown also by the passage of organisms in the last trimester. Spirochaeta pallida can be recovered from foetal tissue, but not before the 6th month (Harris, 1929). Infants have been born with scarlet fever and smallpox rashes (Ballantyne, 1902). Cathepsin, a protease ferment, is present in the placenta, but the part it plays in protein transfusion is unknown, though the local conditions of its activity support anabolism in excess of katabolism (Goldstein and Milgram, 1935).

Fat. Though there is a lipase in the placenta.(Anselmino and Hoffman, 1929), there is no evidence of hydrolysis, but there is ample histological evidence of fat storage. There is a lower colloidal fat concentration in foetal than in maternal blood (Oshima, 1907; Slemons and Stander, 1923). Labelled fats appear in foetal blood and liver, apparently traversing the placenta unaltered. (Bickenbach and Rupp, 1931). Boyd clamped the human umbilical cord at birth and found the fat content increased in the blood between placenta and clamp (Boyd, 1935; Boyd and Wilson, 1935). He inferred active placental transfer of fat. The cells carrying fat are different from those which carry the glycogen, being mainly chorionic villi cells.

Carbohydrate. As has been said above, the sugar gradient supports diffusion in the degenerated types of placenta of carnivora and man, but opposes it in the ungulate, suggesting that decidual epithelium and stroma, when present, can drive sugar from the mother to the foetus against a gradient; or alternatively, that the decidual epithelium inhibits placental diffusion of sugar. The two possibilities are not incompatible.

The placenta in all species has in it glycogen, demonstrable both histologically and chemically. It is in both the foetal and maternal portions, more in the latter, where it attains $\mathbf{5 . 5}$ per cent. at the 2 Ist day in the rabbit, after which it decreases, with a concomitant rise in the foetal liver (Lochhead and Cramer, 1908; Corey, 1935). The two embryonic stores of glycogen, placental and hepatic, differ radically in their 
behaviour. The former is remarkably constant in concentration; the latter fluctuates with maternal blood sugar variations, but more slowly and over a different range. The placental glycogen is unaltered by changes in the maternal blood sugar and by injection into the mother of adrenaline or moderate doses of insulin. It is decreased only by factors causing acute tissue catabolism, such as repeated convulsive doses of insulin, thyroxine or tetrahydronaphthylamine (Huggett, 1929).

The placenta develops in two portions, the foetal or chorionic part and the maternal or decidual part. The latter is apparently a reaction to erosion of the uterine mucosa by the fertilized ovum (Loeb, 1908). Its development in the first part of pregnancy is intimately bound up with the corpus luteum (Allen, 1931; Courrier and Kehl, 1930). In the rat, progesterone, when absorbed from implantations at the rate of $0.4 \mathrm{mg}$. per day (Frazer, Huggett, Pritchard and Tanner, 1942), between the 11th and 16th days of pregnancy, appears to have little or no effect on glycogen deposition. This preliminary study, however, needs considerable extension.

Iron. In the autolysis and necrosis of the placenta, which is physiological in the last stages of pregnancy in the carnivora, rodents and primates, haemorrhages occur. The chorionic villi absorb the red cells and pigment, and, in addition, stagnant blood autolyses, forming a green pigment, uteroverdin (Schick, 1921; Lemberg and Barcroft, 1932). Further, crystals containing inorganic iron are demonstrable (Chipman, 1903). In the carnivora (syndesmo-chorial placenta) this absorbed autolysate forms the main source of nourishment and the green pigment gives the name, placenta verte, to the canine placenta. These deposits of iron are very extensive.

It is a general rule of animal nutrition that when the diet of the pregnant animal is deficient, the embryo has the prior claim (Huggett, 1941). Pregnancy anaemia occurs in women on a diet deficient in iron, but they will deliver themselves of non-anaemic infants (Mackay, 1931). We have no knowledge of how the embryo or the placenta mediates the demand for preferential treatment when supplies are limited. The question is fundamentally important.

Vitamins. The water soluble vitamins appear to pass fairly easily across the placenta. The fat soluble vitamins, however, traverse the placenta more slowly and tend to accumulate in the fat stores. Nothing is known about their mode of passage.

Birth Weight. The diet the mother receives during pregnancy alters the food supply of the foetus and its birth weight but only when it varies over wide limits. It is only one of a number of factors controlling the birth weight. Hammond (1935) has shown that ewes well fed during pregnancy have big lambs; Eckles (1919) found that while diet might affect birth weight, breed was more important. Toverud (1933) found that a good maternal diet in the last month of human pregnancy improved the birth weight. But, as a generalization, this appears to be true only in extremes of low feeding, as in famine. There is the further complication of premature births and their relationship to impoverished diet, which we cannot yet assess. So far as the diet of this country in the present war is concerned, it appears that it has had no definite effect on the average birth weight (Huggett, 1923).

voL. 1,1944$]$ 
The fact that maternal size (breed) largely determines the birth weight is demonstrated by Walton and Hammond's (1938) experiment on the reciprocal crossing of Shire horses and Shetland ponies. They found that the weight of the foal was close to the normal birth weight for the maternal species. The possible explanations are discussed fully in their paper; they suggested that the close correspondence in weight might be due to the maternal anterior pituitary growth factor transfusing the placenta. This tentative explanation does not, however, entirely account for the phenomenon.

\section{Conclusion}

The volume, and to some extent the nature of the substances passing through the placenta, depends upon the placental structure and size. There is a rough proportionality between foetal weight and weight of the foetal part of the placenta (Hammond, 1935). The greater the degree of necrosis of the placenta in late pregnancy, the easier will be the transference. It is not clear how the placenta transfers some of the substances that pass across, nor is anything known of the factors determining the necrosis. Apart from that, we know only that the birth weight depends upon the size (breed) of the mother and the food supplies she can transmit from her current diet or her reserves, coupled with the growth impulse of the foetus.

\section{REFERENCES}

Allen, W. M. (1931). Anat. Rec. 48, 65.

Anselmino, K. J. and Hoffman, F. (1929). Arch. Gynaek. 139, 202.

Ballantyne, J. W. (1902). Manual of Antenatal Pathology. The Foetus, 188; 196. Edinburgh: Wm. Green.

Bickenbach, W. and Rupp, H. (1931). Klin. Wschr. 10, 63.

Boyd, E. M. (1935). Biochem. J. 29, 985.

Boyd, E. M. and Wilson, K. M. (1935). J. clin. Invest. 14, 7.

Chipman, W. (1903). Rep. Lab. R. Coll. Phys. Edinb. 8, Paper 3.

Corey, E. L. (1932). Physiol. Zoöl. 5, 36.

Corey, E. L. (1935). Amer. J. Physiol. 113, 450.

Courrier, R. and KehI, R. (1930). C.R. Soc. Biol., Paris, 104, 1180.

Eckles, C. H. (1919). Bull. Mo. agric. Exp. Sta. no. 35.

Frazer, D., Huggett, A. St. G., Pritchard, J. J. and Tanner, D. (1942). Unpublished observations.

Goldstein, B. and Milgram, E. J. (1935). Ukr. Biochem. J. 8, 139. (Quoted from Nutr. Abstr. Rev. 1935, 5, 1045.)

Grosser, O. (1925). Biologie und Pathologie des Weibes, 6, 1. Berlin: Urban and Schwarzenberg.

Hammond, J. (1932). Groteth and the Development of Mutton Qualities in the Sheep. Edinburgh: Oliver and Boyd.

Hammond, J. (1935). Trud. Dinam. Razvit. 10, 93.

Harris, H. A. (1929). J. Anat., Lond., 64, 1.

Huggett, A. St. G. (1927). J. Physiol. 62, 373.

Huggett, A. St. G. (1929). J. Physiol. 67, 360.

Huggett, A. St. G. (1941). Physiol. Rev. 21, 438.

Huggett, A. St. G. (1942). Unpublished observations.

Lemberg, R. and Barcroft, J. (1932). Proc. roy. Soc. (B), 110, 362.

Levine, P., Burnham, L., Katzin, E. M. and Vogel, P. (1941). Amer. J. Obstet. Gynec. 42, 925.

Lochhead, J. and Cramer, W. (1908). Proc. roy. Soc. (B), 80, 263.

Loeb, L. (1908). Proc. Soc. exp. Biol., N.Y., 5, 102.

Mackay, H. M. M. (1931). Spec. Rep. Ser. med. Res. Coun., Lond., no. 157.

Mason, J. H., Dalling, T. and Gordon, W. S. (1930). J. Path. Bact. 33, 783.

Mossman, H. W. (1926). Amer. J. Anat. 37, 433. 
Needham, J. (1931). Chemical Embryology, 1514-1516; 1531. Cambridge: University Press.

Oshima, T. (1907). Zbl. Physiol. 21, 297.

Ratner, B., Jackson, H. C. and Gruehl, H. L. (1927). J. Immunol. 14, 275.

Rodolfo, A. (1934). J. exp. Zool. 68, 215.

Schick, B. (192I). Z. Kinderheilk. 27, 231.

Slemons, J. M. (1919). Nutrition of the Fetus. New Haven: Yale University Press.

Slemons, J. M. and Stander, H. J. (1923). Johns Hopk. Hosp. Bull. 34, 7.

Toverud, K. U. (1933). Amer. J. Dis. Child. 46, 954.

Walton, A. and Hammond, J. (1938). Proc. roy. Soc. (B), 125, 311.

\section{The Evidence for Nutritional Deficiencies in Pregnancy}

\section{Dr. H. M. Sinclair (Oxford Nutrition Survey, 10 Parks Road, Oxford)}

Dietary deficiencies tend to be revealed more often during pregnancy and lactation than at other times in the life of women, not only because of the increased requirements of the maternal organism, but also because of the common occurrence of nausea and vomiting and of temporary reduction or absence of gastric hydrochloric acid. Antenatal and postnatal clinics are, therefore, places in which evidence of nutritional deficiency might be sought, but they have not so far been used to advantage.

Methods for Obtaining Evidence. Evidence of deficiency may be sought in three ways. First, dietary surveys may be made in which the food consumed by the mother is recorded and its value, in terms of specific nutrients, compared with her estimated requirements (McCance, Widdowson and Verdon-Roe, 1938; Williams and Fralin, 1942). Second, supplements either of foods or of specific nutrients may be given to the mother, and her health and that of her infant compared with those of comparable control subjects. Such tests have been made by the National Birthday Trust Fund (Williams, J. R., 1939), by the People's League of Health (1942) and by the Toronto group (Ebbs, Tisdall and Scott, 1941; Ebbs, Scott, Tisdall, Moyle and Bell, 1942). In tests of this type, the number studied should be large and the results analysed statistically. In the Toronto study, in two comparable but small groups of pregnant women, the pre-experimental records showed a percentage incidence of premature births of 10.7 and 20.3 and of stillbirths of 9.5 and 4.7 . During the study, the incidence of premature births was 2.2 per cent. in the group receiving supplements and 8.0 per cent. in the control group, and of stillbirths 0 and 3.4 per cent. in the two groups. Since the groups were small, it is difficult to know whether the differences in the experimental period were significant.

Third, the nutritional condition of the subjects may be assessed by clinical and biochemical methods that attempt to find the early signs and symptoms of nutritional deficiency. But the clinical signs are in general unspecific and the results of biochemical methods are difficult to interpret. Particular caution is necessary in applying these methods to pregnant women. For instance, temporary reduction or absence of gastric hydrochloric acid is common in pregnancy; this abnormality can be caused by deficiency of nicotinic acid, yet it would obviously be fantastic to suggest that it follows that deficiency of nicotinic acid is common in pregnancy. Another important example is gingivitis, since its presence voL. 1,1944$]$ 
is frequently taken to indicate deficiency of either vitamin $\mathrm{C}$ or nicotinic acid. Marginal gingivitis and hypertrophy of the gums are common during pregnancy, appearing about the middle of the period and continuing until after parturition. They are also occasionally observed at the menstrual periods. Ziskin, Blackberg and Stout (1933) have described four forms of pregnancy gingivitis: bleeding, a raspberry coloured free gum margin, generalized hypertrophy, and localized epithelial hyperplasia affecting a single papilla, resembling an epulis, and disappearing after parturition. No doubt many of these cases of gingivitis bear no relation to nutritional deficiency since Ziskin (1937) has shown that, in animals, administration of oestrogens causes epithelial hyperplasia of the gums.

Interpretation of the Evidence. Another difficulty arises in the interpretation of analyses of blood. A rise in plasma phosphatase is normal in pregnancy and is no indication of defective absorption of calcium. More important, in pregnancy there is usually an increase in plasma volume which averages about 5 per cent. in the first, 10 per cent. in the second and 15 per cent. in the third trimester, but which does not occur in all cases (Dieckmann and Wegner, 1934; Richter, Meyer and Bennett, 1934). This must be borne in mind in interpreting haematological results or estimations of certain vitamins in whole blood e.g., vitamin $B_{1}$ which is present mainly in the cells. Unless the blood volume is also estimated, determinations of vitamin $\mathrm{C}$ in the leucocyte platelet layer of blood or of vitamin A, carotene or protein in plasma are more trustworthy because they are much less affected by hydraemia.

Physiological hydraemia is one cause of the oedema that not uncommonly occurs in the later stages of pregnancy; Weiss (1940) found evidence of some degree of generalized oedema in 64 per cent. of normal pregnant women. Other possible causes are, increased venous pressure, diminished plasma protein, cardiac or renal or mechanical causes, increased amounts of oestrin in the blood and increased permeability of the capillaries. Arnell and Guerriero (1942) have recently studied 500 cases of pregnanoy oedema, 8 of whom had gross oedema and marked dietary deficiencies, of which protein was considered to be the most important; three of the cases showed plasma protein values below 4 per cent. and the mean of all 8 was $4 \cdot 2$. Since, under normal conditions, about $1 \mathrm{~kg}$. of protein may be retained during pregnancy, it is not surprising that deficiency of protein may occur on poor diets. Melnick and Cowgill (1937) found that the protein reserves of pregnant dogs were always low and, as shown by Whipple and Robscheit-Robbins (1942), protein deficiency may produce ills other than oedema, because it favours liver injury and impairs the defences against infection.

Major Deficiencies in Pregnancy: Causes and Treatment. Whipple and Robscheit-Robbins (1942) have also shown that the iron stores of the body are very low in late pregnancy and this, combined with deficiency of protein and hydraemia, is an important causc of anaemia. The anaemia that is caused by hydraemia alone may be called physiological since the increase of blood volume in pregnancy is normal. There are two main pathological types, iron deficiency and macrocytic anaemia. In the last two months of pregnancy the iron content of the foetus increases at the rate of about $5 \mathrm{mg}$. daily and, therefore, iron deficiency 
anaemia might be expected to arise. But Davidson and Fullerton (1938) consider that the anaemia antedates pregnancy, is slightly exaggerated by hydraemia and is due mainly to a dietary iron intake insufficient to balance the losses of menstruation. Strauss (1934) clearly distinguished between the hydraemia of pregnancy and iron deficiency anaemia; more than half his cases of iron deficiency anaemia showed a marked reduction or absence of free hydrochloric acid, the decrease corresponding with the severity of the anaemia; after parturition, gastric acidity returned to normal. Work in this country before the war showed that iron deficiency anaemia in pregnancy was prevalent and it appears to have increased during the war.

Other nutritional causes of anaemia in pregnancy are deficiency of protein (Bethel, 1936), vitamin C or the extrinsic factor. Two types of macrocytic anaemia occur, one similar to pernicious anaemia, except that free hydrochloric acid is present in the stomach, and a rarer refractory type of which the precise aetiology has not been determined. A striking case which was possibly due to deficiency of the extrinsic factor was recently studied by Daniel and Antis (1942). From the second month of pregnancy onwards, a woman lived on small amounts of cereal, vegetables and milk and, during the last two months, took only two glasses of milk and water daily; her haemoglobin level was 18 per cent., red cells 850,000 per c.mm., haematocrit 12 per cent. and serum protein 4.9 per cent; gastric acidity was normal.

Deficiency of protein in the diet was believed by Strauss (1935) to be an important cause of pre-eclamptic toxaemia, since it would produce a low osmotic pressure of plasma. It might also act by favouring liver injury from the toxic substances postulated in Young's theory (Whipple and Robscheit-Robbins, 1942). But Dieckmann and Kramer (1941) found no significant alteration in serum protein or in the albumin : globulin ratio in pre-eclamptic toxaemia or eclampsia. Other possible dietetic origins of these conditions have been postulated. Theobald (1930) believed that deficiencies of several vitamins and minerals all played a part, but that deficiency of calcium was the most important single cause. Some experimental support for this view was obtained by Mendenhall and Drake (1934), who reduced the incidence of toxaemia by the administration of calcium. However, the calcium might act as a drug, protecting the liver from the action of some toxic substance, and this view, rather than the calcium deficiency hypothesis, is perhaps supported by the fall in the incidence of eclampsia, combined with a rise in the incidence of osteomalacia, in Germany during the last war.

More recently a new hypothesis has been set up, namely, that deficiency of vitamin $B_{1}$ plays an important part. Siddall (1940) was led by geographical and other considerations to put forward this view, although administration of vitamin $B_{1}$ did not affect the blood pressure, oedema or symptoms in his cases. Yasunami (1938), however, had found treatment with vitamin $B_{1}$ valuable in toxaemia, particularly in preventing convulsions. King (1941) has called attention to the frequent association of toxaemias of pregnancy with avitaminosis $B_{1} ; 30$ per cent. of his 42 patients with eclampsia died, and the death of most of them was due to complicating beriberi. Nixon, Wright and Fieller (1942) have found diminished excretion of vitamin $B_{1}$ in cases of toxaemia. It should

voL. 1,1944$]$ 
also be mentioned that Willis, Winn, Morris, Newsom and Massey (1942) claim that almost complete relief from the nausea and vomiting of pregnancy follows administration of vitamin $B_{1}$ or $B_{6}$, preferably the latter. It seems certain that there is a disturbance of carbohydrate metabolism in eclampsia similar to that occurring in deficiency of vitamin $B_{1}$. Stander and Radelet (1926), for instance, found an increase in blood lactate, especially after a fit, when the increase might be as much as 200 per cent.; this was apparently not due to the fit itself since blood lactate was normal after an epileptic fit. Penfold (1941) has described eclampsia as an acute intoxication with lactic acid, but it remains unproved that a dietary deficiency of vitamin $B_{1}$ is responsible for this biochemical disturbance of carbohydrate metabolism.

Deficiency of vitamin $B_{1}$ has also been alleged to be the cause in pregnancy of certain ocular changes, Wernicke's encephalopathy and polyneuritis, usually following hyperemesis. As Ballantyne (1941) and others have shown, the primary ocular disturbance is a retrobulbar neuritis with dimness of vision but with no visible change in the fundi, followed by a central scotoma with some oedema of the discs and, later still, by retinal haemorrhages, papilloedema and complete loss of vision, without exudates or vascular sclerosis. Ballantyne was inclined to fivour the therapeutic use of vitamins $B_{1}$ and $C$ for this retrobulbar neuritis, but there is increasing evidence (Moore, 1939; Landor and Pallister, 1935; Wilkinson and King, 1941; Grande and Peraita, 1941) that, in non-pregnant persons, retrobulbar neuritis is caused by deficiency of a member of the vitamin $B_{2}$ complex, perhaps riboflavin. Wernicke's encephalopathy has been stated to respond dramatically to treatment with vitamin $B_{1}$, but there is some evidence that nicotinic acid, with or without vitamin $B_{1}$, produces better results. It is possible that deficiency of nicotinic acid, at least in an acute form, can produce encephalopathic states and, as far as is known, these do not occur in acute beriberi. Nevertheless, Swank and Prados (1942), by inducing acute deficiency of vitamin $B_{1}$, have produced in pigeons lesions identical with those of Wernicke's disease in man; they have also produced peripheral neuropathy in pigeons by inducing chronic deficiency of vitamin $B_{1}$. Many have claimed that polyneuritis of pregnancy is due to deficiency of this vitamin but no one has proved it; in most therapeutic tests, other substances have been given along with vitamin $B_{1}$. McGoogan (1942), for instance, has recently described 15 cases of his own but none was given vitamin $B_{1}$ alone; three had blurred vision and one had retrobulbar neuritis. He reviews 130 other cases which had a total mortality of 27.5 per cent., 7.5 per cent. in those receiving vitamin $B$ complex and 35.2 per cent. in those not so treated. Though paraesthesiae are common in pregnancy, severe neuritis is rare and when it occurs it usually follows hyperemesis. There is no doubt that deficiency of vitamin $B_{1}$ tends to occur in pregnancy because of the increased requirement, loss in vomiting and failure of absorption due to achlorhydria. Williams, Griffith and Fralin (1940) have shown in dietary studies that deficiency occurs and, in 1937, I found significantly low values for vitamin $B_{1}$ in the blood of one-third of poor women attending an antenatal clinic.

These are some of the conditions occurring in pregnancy that are believed to be due to dietary deficiency, Other relations, proved or 
suggested, exist, for example, between calcium deficiency and rickets, osteomalacia and dental caries; between iodine deficiency and colloid goitre (Yoakham, 1928); between deficiency of vitamin $\mathbf{E}$ and sterility or habitual abortion (Shute, 1942); between deficiency of vitamin A and puerperal sepsis (Green and Mellanby, 1928); between deficiency of vitamin $\mathrm{C}$ or $\mathrm{K}$ and accidental haemorrhage and haemorrhagic tendencies (Hellman, Shettles and Eastman, 1940). There can be no doubt about the importance of dietary deficiencies in pregnancy, and as little doubt about our ignorance of them. The Oxferd Nutrition Survey is engaged in making detailed examinations of the nutritional condition of women attending an antenatal clinic; probably the most common deficiencies are of iron, calcium, protein and vitamins $\mathrm{A}$ and $\mathrm{C}$. These deficiencies can and should be prevented, especially in pregnancy, where the health, and even the life, of the mother and child are at stake. They are better prevented by food than by pills. Vitamins should be bought from the grocer and not from the chemist.

\section{REFERENCES}

Arnell, R. E. and Guerriero, W. F. (1942). Amer. J. Obstet. Gynec. 43, 467.

Ballantyne, A. J. (1941). J. Obstet. Gynaec. 48, 206.

Bethel, F. H. (1936). J. Amer. med. Ass. 107, 564.

Daniel, M. and Antis, M. (1942). Amer. J. Obstet. Gynec. 44, 93.

Davidson, L. S. P. and Fullerton, H. W. (1938). Edinb. med. J. 45, 1.

Dieckmann, W. J. and Kramer, S. (1941). Amer. J. Obstet. Gynec. 41, 1.

Dieckmann, W. J. and Wegner, C. R. (1934). Arch. intern. Med. 53, 71.

Ebbs, J. H., Scott, W. A., Tisdall, F. F., Moyle, W. J. and Bell, M. (1942). Canad. med. Ass. J. 46, 1.

Ebbs, J. H., Tisdall, F. F. and Scott, W. A. (1941). J. Nutrit. 22, 515.

Grande, F. and Peraita, M. (1941). Avitaminosis y Sistema Nervioso. Madrid: Editorial Miguel Servet.

Green, H. N. and Mellanby, E. (1928). Brit. med. J. ii, 691.

Hellman, L. M., Shettles, L. B. and Eastman, N. J. (1940). Amer. J. Obstet. Gynec. 40, 844.

King, G. (1941). Caduceus, 20, 45 .

Landor, J. V. and Pallister, R. A. (1935). Trans. R. Soc. trop. Med. Hyg. 29, 121.

McCance, R. A., Widdowson, E. M. and Verdon-Roe, C. M. (1938). J. Hyg., Camb., 38, 596.

McGoogan L. S. (1942). Amer. J. Obstet. Gynec. 43, 752:

Melnick, D. and Cowgill, G. R. (1937). J. exp. Med. 66, 509.

Mendenhall, A. M. and Drake, J. C. (1934). Amer. J. Obstet. Gynec. 27, 800.

Moore, D. F. (I939). J. trop. Med. (Hyg.), 42, 109.

Nixon, W. C. W., Wright, M. D. and Fieller, E. C. (1942). Brit. med. J. 1, 605.

Penfold, W. J. (1941). Med. J. Aust. 11, 198.

People's League of Health (1942). Lancet, 243, 10.

Richter, O., Meyer, A. E. and Bennett, J. P. (1934). Amer. J. Obstet. Gynec. 28,543 .

Shute, E. (1942). J. Obstet. Gynaec. 49, 534.

Siddall, A. C. (1940). Amer. J. Obstet. Gynec. 39, 878.

Stander, H. J. and Radelet, A. H. (1926). Johns Hopk. Hosp. Bull. 38, 423.

Strauss, M. B. (1934). J. Amer. med. Ass. 102, 281.

Strauss, M. B. (1935). Amer. J. med. Sci. 190, 811.

Swank, R. L. and Prados, M. (1942). Arch. Neurol. Psychiat., Chicago, 47, 97.

Theobald, G. W. (1930). Lancet, 218, 1115.

Weiss, S. (1940). New Engl. J. Med. 223, 939.

Whipple, G. H. and Robscheit-Robbins, F. S. (1942). J. exp. Med. 76, 283.

Wilkinson, P. B. and King, A. (1941), Caduceus, 20, 13.

Williams, J. R. (1939). Publ. Hlth, Lond., 52, 314.

Williams, P. F. and Fralin, F. G. (1942). Amer. J. Obstet. Gynec. 43, 1.

Williams, P. F., Griffith, G. C. and Fralin, F. G. (1940), Amer. J. Obstet. Gynec. 40,181 .

voL. 1,1944$]$ 
Willis, R. S., Winn, W. W., Morris, A. T., Newsom, A. A. and Massey, W. E. (1942). Amer. J. Obstet. Gynec. 44, 265.

Yasunami, H. (1938). Jap. J. Obstet. Gynec. 21, 239.

Yoakham, W. A. (1928). Amer. J. Obstet. Gynec. 15, 617.

Ziskin, D. E. (1937). J. dent. Res. 16, 367.

Ziskin, D. E., Blackberg, S. N. and Stout, A. P. (1933). Surg. Gynec. Obstet. 57,719 .

\section{The Effect of Maternal Diet on the Viability of the Foetus. A Review of the Present State of our Knowledge}

\section{In Human Beings}

\section{Professor D. Baird (Department of Midwifery, University of Aberdeen)}

The wastage of foetal life in pregnaney and labour can be most conveniently estimated by adding together the stillbirths and the neonatal mortality. This does not give a completely accurate estimate, since some of the deaths in the neonatal period are probably not connected with the health of the mother during pregnancy or with the labour. No account is taken of abortion, since the incidence of abortions is difficult to assess and accurate information as to cause is usually difficult to obtain. That the mortality in young infants is considerable is seen from the fact that in 1936 in England and Wales there were 25,045 stillbirths and 18,004 neonatal deaths. In Scotland the combined stillbirth and neonatal mortality rate is about 80 per 1000 births (about 7000 annually). The neonatal deaths constitute about half of the deaths in the first year of life (infant mortality). We have to consider how much of this mortality is due to deficiont maternal diet.

Tests for nutritional deficiencies are difficult to make on the human subject, but the prevalence of anaemia during pregnancy, which has been shown by Davidson and others, suggests that deficiencies of some of the constituents of the diet are frequent. Dietary surveys in recent years in Britain show that there is much malnutrition among the population generally. It is known that the amount of money available for food diminishes steadily as the size of the family increases, so that many expectant mothers with several previous children are almost certain to have a deficient diet.

The League of Nations Health Committee Technical Commission (1936) laid down that the pregnant woman should take daily: 2 pints of milk, $\frac{1}{4} \mathrm{lb}$. of meat, l egg, l oz. of cheese, $3 \frac{1}{4} \mathrm{oz}$. of green leafy vegetable, $8 \frac{1}{2} \mathrm{oz}$. potatoes, $\frac{1}{2} \mathrm{oz}$. of dried legumes, some raw fruit, 1 teaspoonful of cod liver oil. All this in addition to the amounts of bread, butter and sugar necessary to make up the energy requirement. At pre-war prices this would cost about 10 shillings and sixpence per week.

It is now well recognized that high infant mortality is closely associated with poverty and all that goes with it, bad housing, poor food, ignorance and poor medical attention. The same factors may affect the stillbirth and neonatal mortality rates. Table 1 shows that, where the stillbirth rate is high, the neonatal and infant mortality rates are high and vice versa. Table 2 shows the neonatal mortality in different economic classes. 
TABLE I

Mortalities at Different Ages Compared, 1939

Rates fer 1000 Total Births

\begin{tabular}{lr|c|c|c|c|c}
\hline \multicolumn{1}{c|}{ Country } & Stillbirths & $\begin{array}{c}\text { Neonatal } \\
\text { deaths }\end{array}$ & $\begin{array}{c}\text { Stillbirths } \\
\text { and neonatal } \\
\text { deaths }\end{array}$ & $\begin{array}{c}\text { Deaths I to } \\
\text { 12 months }\end{array}$ & $\begin{array}{c}\text { Total } \\
\text { mortality }\end{array}$ \\
\hline New Zealand &. & 30 & 21 & 51 & 9 & 60 \\
Holland (1938) &. & 25 & 21 & 46 & 15 & 61 \\
Canada & 27 & 30 & 57 & 29 & 86 \\
England and Wales & 38 & 27 & 65 & 21 & 86 \\
Scotland .. &. & 42 & 35 & 77 & 31 & 108 \\
\hline
\end{tabular}

TABLE 2

Neonatal Mortality of Legitimate Infants According to the Registrar Gteneral's Classification of Soctal Class of Father, ENGLAND AND WALES, 1930-1932

Rate per 1000 legitimate live births

\begin{tabular}{c|c|c|c|c|c}
\hline All classes & I & II & III & IV & V \\
\hline 30.2 & 21.7 & 27.2 & $29 \cdot 4$ & 31.9 & 32.5
\end{tabular}

TABLE 3

Causes of Stillbirth: Scotland, 1939

(Preliminary Returns: Registrar General for Scotland)

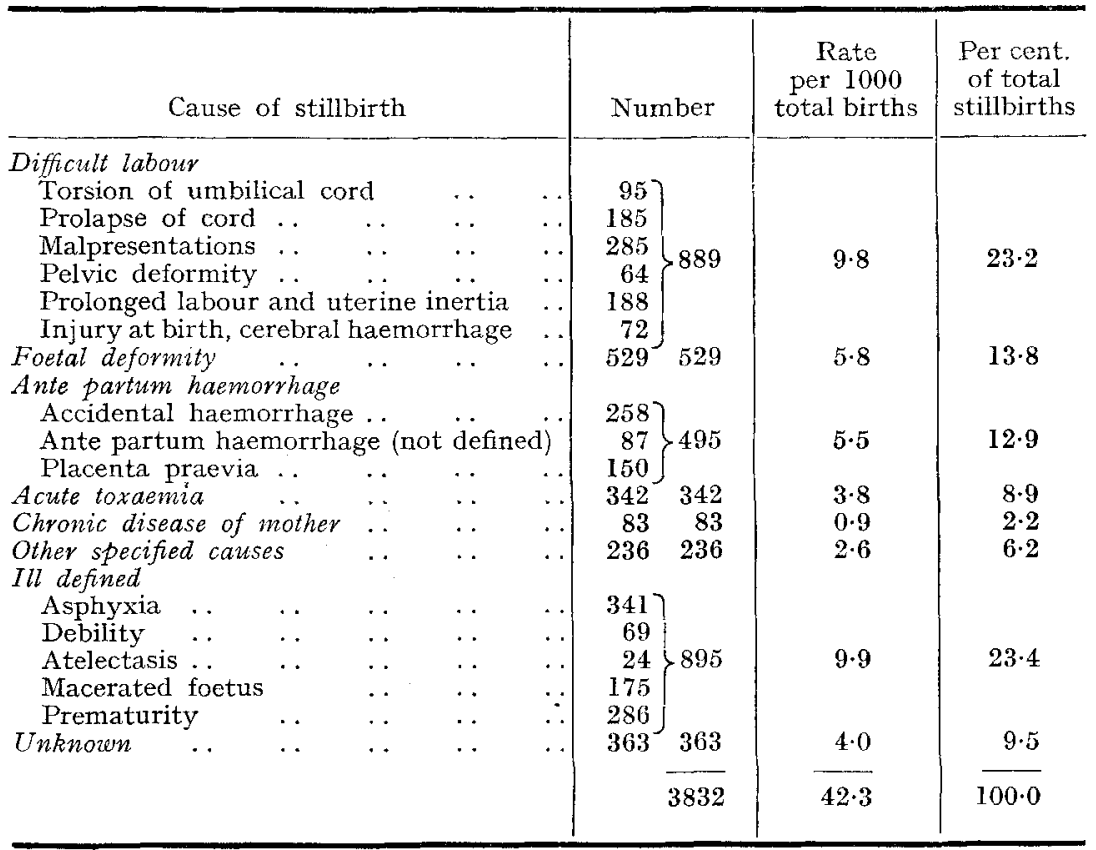

VOL, 1,1944$]$ 
Stillbirths. The cause of stillbirth is often difficult to determine. Table 3 gives an analysis of the stillbirths in Scotland in 1939. It shows that, in 33 per cent. of cases, no satisfactory explanation of the cause of death could be found. Where the birth does not take place inside a maternity hospital attached to a medical school this is not altogether surprising, since clinical data are scanty and post mortem examination is the exception rather than the rule. In an analysis of stillbirths in booked hospital cases where those handicaps did not exist, it was found that in 36 per cent. of full time babies the cause of the stillbirth was unexplained. It is true that post mortem examination showed that, in some of these cases, the child died of asphyxia or atelectasis, but, as the health of the mother during pregnancy had been regarded as good and the labour normal, this finding does not explain adequately why the child died. Even in some cases where the child died of a cerebral haemorrhage and the death was classified as due to trauma, the labour, from the clinical standpoint, was not regarded as difficult. It is possible that some of those babies were unduly susceptible to injury. Premature babies stand labour badly and every effort should be made to avoid prematurity. No cause could be found for the premature onset of labour in 30 per cent. of the stillbirths in premature babies.

Neonatal Mortality. Many of the causes of stillbirth operate also during the neonatal period. Prematurity is again an important cause of death and, out of a series of 79 premature babies dying, no cause for the premature onset of labour could be found in 40 per cent. of cases. A great deal can be done by careful nursing and medical care to lower the mortality among premature babies, but out of a series of 67 neonatal deaths in premature babies 45 died within 3 days of birth because of weakness. Every effort should be made therefore to prevent prematurity.

I have recently made a comparison between booked hospital cases (a) and upper middle class patients attending their family doctor $(b)$, or attending a specialist $(c)$. The results are summarized in Table 4.

TABLE 4

\begin{tabular}{c|c|c|c|c}
\hline Group & $\begin{array}{c}\text { No. in } \\
\text { group }\end{array}$ & $\begin{array}{c}\text { Percentage of } \\
\text { stillbirths }\end{array}$ & $\begin{array}{c}\text { Percentage of } \\
\text { neonatal deaths }\end{array}$ & $\begin{array}{c}\text { Percentage of } \\
\text { premature labours }\end{array}$ \\
\hline$(a)$ & 4826 & $3 \cdot 3$ & $3 \cdot 3$ & 9 \\
$(b)$ & 885 & $3 \cdot 95$ & $1 \cdot 35$ & 6 \\
$(c)$ & 330 & $0 \cdot 6$ & $0 \cdot 6$ & 2 \\
\hline
\end{tabular}

The high stillbirth rate in group $(b)$ was probably due to the fact that the obstetrical care was not uniformly good and there was a relatively high proportion of primigravidae. The neonatal mortality in $(b)$ and $(c)$ is low because of good nursing and the small number of very small, premature, babies encountered. In $(c)$ and $(a)$ the medical care was of much the same standard so that the difference between the rates is probably due to difference in the type of patient. The factor most likely to account for this difference is the diet of the mother during pregnancy, although the more remote effect of diet in the mother's early years must be borne in mind, 
Some of the earliest evidence that special feeding of expectant mothers might lessen infant mortality was obtained in the Rhondda Valley in the strike of 1926 (Williams, 1936), when the infant mortality rate fell from 96 to 69 per 1000 . This was in contrast with what had happened in the strike of 1921, when there was no special feeding and the mortality rose.

In March, 1939, the Joint Council of Midwifery (1939) circulated a report on the feeding of expectant mothers and babies in the north east of England. The women were given: marmite $1 \frac{1}{2} \mathrm{lb}$., ovaltine $3 \mathrm{lb}$, dried milk $6 \mathrm{lb}$., in the last 3 months of pregnancy, and in addition 1 pint of liquid milk per day. These foods were distributed by the Medical Officers of Health to necessitous cases at the antenatal clinies for a period of 10 weeks before and 3 weeks after confinement. In the clinic patients fed in this way the combined stillbirth and neonatal mortality rate was 58 per 1000 births. In the clinic cases not fed the rate was 71 and in non-clinic patients in the same area it was 92. Experimental conditions were not rigidly controlled and the results, in the opinion of the investigators, were open to some doubt on that account. More recently, Ebbs, Tisdall and Scott (1941) published the results of a feeding experiment in Toronto. They divided their patients into 3 groups: (1) Where the diet was poor; (2) where the poor diet, similar to that found in Group 1, was supplemented by actual foodstuffs distributed to the homes; (3) where the diet was also poor but the mother could afford to buy adequate food but had not done so. Here only advice was given as to what should be eaten. It was found that the percentage incidence of premature labour in the 3 groups was $8 \cdot 0,2 \cdot 2$ and $3 \cdot 0$ respectively and of stillbirth was $3 \cdot 4,0 \cdot 0$ and $0 \cdot 6$. Although the experiment was carefully done it suffered from the defect that the numbers in the three groups were very small, 120,90 and 170 respectively, and, judging by the previous obstetrical histories of the cases, there was some doubt as to whether the groups were strictly comparable. The incidence of successful breast feeding six weeks after birth was higher in the fed group, 86 per cent. as against 59 per cent. in the control group. While the conclusions must be treated with some reserve, they are so suggestive that a repetition on a larger soale is desirable.

The People's League of Health (1942) published a survey of the records of 5000 cases investigated during the years 1938 and 1939 . To the group under investigation they gave pills containing saccharated iron carbonate, calcium lactate, minute quantities of iodine, manganese and copper, adsorbate of vitamin $\mathrm{B}_{1}$ and $\mathrm{B}$ complex, vitamin $\mathrm{C}$ and halibut liver oil. In primigravidae they found that the incidence of pre-eclamptic toxaemia was $5 \cdot 4$ per cent. as against 7.4 per cent. in the control group. The incidence of premature births was $20 \cdot 1$ per cent. as against 23.9 per cent. in the control group, prematurity being defined as labour starting any time before the beginning of the 40th week. The investigators did not think that the diet was deficient in first class protein, but there was a shortage of calcium in 70 per cent. of the cases. Most of the women were consuming insufficient quantities of milk and cheese. Iron deficiency was even more serious; only 2 per cent. seemed to have a satisfactory intake.

It is interesting to note that the incidence of pre-eclamptic toxaemia in primigravidae in booked hospital cases in Aberdeen was 8.2 per cent. voL. 1,1944$]$ 
and in specialist practice $3 \cdot 6$ per cent. It seems possible, therefore, that a good diet will diminish the risk of pre-eclampsia. This would affect the stillbirth and neonatal mortality by decreasing the risk of intra-uterine death, the incidence of premature labour, either induced or spontaneous, and the risk of premature separation of the placenta with or without haemorrhage.

There is some evidence, therefore, from direct observations on women, that deficient diet during the antenatal period will increase the incidence of stillbirth and neonatal mortality, but more direct evidence from feeding experiments and biochemical investigations is required to settle the matter finally.

\section{REFERENCES}

Ebbs, J. H., Tisdall, F. F. and Scott, W. A. (1941). J. Nutrit. 22, 515.

Joint Council of Midwifery Research Committee (1939). Interim Report upon the Nutrition Experiments in the Special Aveas.

League of Nations Health Committee. Technical Commission (1936). Quart. Bull. Hlth Org. L.o.N. 5, 391.

People's League of Health (1942). Brit. med. J. ii, 77.

Williams, Lady (1936). Publ. Hith, Lond, 50, 11.

\section{In Animals}

Mr. W. Godden (Rowett Research Institute, Bucksburn, Aberdeen)

\section{General}

In animal husbandry much less attention has been given to foetal and infant mortality than the problem deserves. This is mainly because, to the farmer who raises stock for profit, the problem is largely academio.

In the dairy herd milk yield is the important consideration and problems of disease and slow breeding or sterility in the cow completely overshadow calf rearing difficulties. With sheep the rearing of less than one lamb per ewe yearly is still profitable, although much higher lamb crops may be obtained. With poultry the point of interest is total egg yield. The fact that the hatch from eggs set. for rearing may be only 80 or 50 per cent. is a matter of indifference as compared with problems of disease in the flock.

Thus little accurate information exists on foetal and infant mortality under ordinary conditions and, in general, only conditions that have produced or threatened serious financial loss have been investigated.

Equally unsatisfactory is our information with respect to small experimental animals, e.g., rats, where conditions of colony management tend to restrict the information available.

\section{Farm Animals}

Mortality Rates. Sows are stated to shed on the average 20 ova at one time. Of these, some disappear and about 15 , but seldom 20 , are im. planted. A number of those implanted atrophy and may disappear so that, usually, only 12 or 13 viable foetuses result.

Records by Jespersen and H. M. Olsen (1939) of 2392 litters, including over 27,000 pigs born at 3 Danish experimental farms over a period of 7 years, show that the average number of pigs per litter was 11.45. Stillbirths, expressed as a percentage of total births, varied from 5 per cent. in litters 
averaging 6 up to 11 per cent. in litters averaging 15 . The average number per litter born alive was 10.62 and the percentage dying during the suckling period increased from 13.4 for litters of 6 to $50 \cdot 6$ for litters of 19 , with an over all average of $21 \cdot 3$. Postnatal mortality was highest during the first week at 12.2 per cent., half of it probably being due to accident, and thereafter it decreased rapidly to 0.9 per cent. in the 5th and 6th weeks.

According to the Report of the Poultry Technical Committee for Great Britain (Ministry of Agriculture and Fisheries, 1938) the hatch, as a percentage of eggs set, varies from 50 to 85 and usually lies between 60 and 75. Many of the chicks hatched are too weak to survive.

The loss of lambs varies from over 20 per cent. on poor grazings to between 5 and 10 per cent. under conditions of good management and feeding.

The magnitude of these losses is undoubtedly dependent to a large extent on diet, the amount and individual constituents playing a part. Other factors are exercise, access to air and sunlight, housing and management.

\section{The Influence of Diet}

Energy Supply. An adequate supply of energy is essential to successfu reproduction. Acute shortage is liable to cause interruption of pregnancy and abortion. While it is truc that, in systems of farming as practised in this country, farm animals are usually fed so that they improve in condition during pregnancy, this is not invariably the case.

Under range conditions, where the pasture is poor, particularly in seasons of drought, sterility is liable to occur and losses among newborn calves are high. Supplementary feeding with concentrates, roughages and minerals results in a marked improvement in breeding with increase in birthweight and lower mortality of calves.

The beneficial effect of nutritional "flushing" of ewes prior to or at mating with respect to number of twins dropped and percentage of lambs reared is well known. Equally important is adequate feeding during gestation. A marked drop in the energy intake of breeding ewes, particularly during the last month of pregnancy, is liable to cause ketonaemia and hypoglycaemia and the onset of pregnancy disease. Fraser, Godden, Snook and Thomson (1939) and Fraser and Thomson (1939) found that underfeeding during pregnancy resulted in the production of undersized and weak lambs.

Hogan and Mackenzie (1931) have shown that keeping gilts on medium or low planes of nutrition results in a delay of the first pig crop, and the production of litters below the average in size at birth and at weaning. The importance of having large, vigorous and thrifty pigs at farrowing is well recognized because of the higher percentage surviving to weaning and the more rapid gains in weight.

Equally important is attention to supplying adequate feeding to the dam during lactation. At this stage cows are normally stall fed according to milk yield or pastured on good grass, with concentrates if necessary, not so much for the sake of the calf as for the benefit of human consumers. Ewes, on the other hand, are not always so well treated and, if poor feeding during lactation follows on underfeeding during pregnancy, voL. I, 1944] 
lactation may fall. In this country sows are usually inadequately fed during lactation and lose heavily in condition. Such treatment is almost certain to result in restricted milk production and this may be in part responsible for the high mortality of young pigs during the suckling period.

Protein Intake. There are undoubtedly optima for the protein content of the diet during both pregnancy and lactation. The number, size and viability of the young at birth are affected and the yield of milk, as is well known, is dependent on an adequate supply of protein. There is evidence that a pregnant sow requires an increase in its protein supply of about 30 per cent. over maintenance. Less comprehensive studies on the cow suggest that an increase of about 17 per cent. is required. According to Davidson (1930), who used blood meal as the main source of protein to supplement a cereal ration, partial foetal atrophy in sows was not due to any deficiency of protein in the ration.

In a study of embryonic mortality in the chick, Graham and Smith (1929, quoted from McFarlane, Fulmer and Jukes, 1930) concluded that the diet of the laying hen, particularly in regard to supply of protein and fat soluble vitamins, has a profound influence on the extent and distribution of mortality during incubation. Supplementation of cereal grains and grain products with suitable protein is necessary and McFarlane, Fulmer and Jukes (1930) have emphasized the importance of selecting the right type of protein. They obtained wide differences in hatchability and in the percentage of dead embryos with different proteins, but they were unable from their biochemical data to offer any further explanation of their findings.

Mineral Intake. Adequate supplies of both calcium and phosphorus are necessary for the birth of normal young. Maternal reserves may be adequate to meet the demands of one pregnancy and lactation, but if reproduction is continued without making good deficiencies, the results will become steadily worse. Davidson (1930) considered that calcium deficiency might be a factor contributing to the occurrence of foetal atrophy in sows and established experimentally that it required two or three generations for the effect to become pronounced because of the utilization of body reserves. After that there was a considerable increase in the number of pigs born dead and in the liability to fatal accidents among the young pigs.

Reproductive failures due to phosphorus deficiency in range cattle have been reported from South Africa, but work in America would suggest that this is not a simple phosphorus deficiency but that probably other factors, including protein, are also involved.

Anaemia in the mother does not appear to affect fertility. It does affect, however, not only the viability of the young during the suckling period, but also the health and development at much later ages. In extreme conditions of iron deficiency brood sows have been found to suffer severely from anaemia and give birth to stillborn but otherwise normal litters. Administration of iron to the sows during subsequent pregnaneies resulted in healthy normal litters. In pigs, anaemia in the sow affects the haemoglobin at birth and this in turn affects the growth of the young pigs. Jespersen and N. J. H. Olsen (1939) report a marked positive correlation between haemoglobin level at 2 weeks and gain in weight to 8 weeks and a marked negative correlation with mortality 
between 2 and 8 weeks. Hence the well known advice to supply iron in some form to the suckling pig. Iron is of importance for poultry. The haemoglobin level of the hen's blood rises and falls with the rate of egg laying. A severe anaemia is liable to occur in embryo chicks, which is responsible for a high mortality at an early stage of development.

Attention needs to be paid to the supply of adequate amounts of certain "trace" elements. Thus deficiencies of iodine, manganese and copper give rise, in different classes of stock, to foetal and infant deaths or abnormalities. On the other hand, the presence of selenium, in all but the most minute amounts, in poultry food causes marked detrimental effects, reducing hatchability and often causing embryo mortality to reach 100 per cent.

Vitamins. For the proper development and function of the female reproductive organs, adequate supplies of certain vitamins are deemed necessary.

Vitamin $A$ is essential during pregnancy, and certain forms of blindness present at birth are directly connected with a lack of this vitamin in the maternal diet. Troubles of this character have been found in the newborn young of cows, ewes and sows on diets deficient in vitamin A, although, it should be noted, the requirements of a cow for vitamin A can be met by a supply of only 2 to $3 \mathrm{lb}$. of fresh pasture daily.

There is no evidence that deficiency of vitamin $B_{1}$ has any effect other than that due to the resultant anorexia.

Deficiency of riboflavin has a marked influence on the number of eggs laid and on the embryo mortality in chicks.

Deficiency of vitamin $D$ is known to affect the viability of the mammalian foetus and this vitamin is necessary to poultry both for egg production, correct texture of shell and hatchability.

There is no evidence that, under normal conditions, vitamin E deficiency occurs in farm animals or that, in poultry with good housing and diet and with access to grass, the addition of vitamin $\mathrm{E}$ affects either fertility or the hatchability of eggs.

\section{Laboratory Animals}

What has been said with regard to the effect of deficiencies in the maternal diet in farm animals applies equally in the main to laboratory animals and sometimes the effects are more acute.

Lowering of food intake in young rats results in late opening of the vagina and a lengthening of the period before the first oestrus, but there is no evidence of loss of reproductive capacity. The amount and nature of the protein supply to rats affects the number of young per litter and their rate of liveweight increases. With rats, the vital need of the body for certain unsaturated fatty acids has also been shown.

Reproduction and lactation are affected both by the actual levels of calcium and phosphorus intakes and by their ratios. Rats on a diet deficient in iron may produce one litter showing no anaemia at birth but a second litter will cause a severe anaemia in both mother and young. Duckworth (1939) has drawn attention to the fact that rats on a diet deficient in magnesium can bear normal young but are unable to suckle them. Such young as do survive show the characteristic signs of vasodilatation and hyperirritability. Convulsions in calves have been cured voL. 1,1944$]$ 
by magnesium therapy but, apart from this, there is no evidence as to the requirements of farm animals for magnesium,

Vitamin A deficiency in rats has been shown to cause prolongation of the gestation period and, in severe cases, long and difficult labour. Foetal deaths and resorptions have been noted and very few of the young cast alive survived.

Although vitamin $\mathbf{E}$ deficiency does not appear to be of primary importance in farm animals, it has been intensively studied in rats. The effect of vitamin $\mathrm{E}$ on the development of the rat embryo is exerted on the embryo side of the foetal membrane. Transmission across the placenta is therefore necessary and this becomes increasingly difficult with age so that restoration of fertility becomes less and less easy as age advances.

\section{REFERENCES}

Davidson, H. R. (1930). J. agric. Sci. 20, 233.

Duckworth, J. (1939). Nutr. Abstr. Rev. 8, 841.

Fraser, A. H. H., Godden, W., Snook, L. C. and Thomson, W. (1939). J. Physiol. 97, 120 .

Fraser, A. H. H. and Thomson, W. (1939). Scot. J. Agric. 22, 71.

Graham, W. R. and Smith (1929). Report to the British Empire Marketing Board (London).

Hogan, A. G. and Mackenzie, F. F. (1931). Scot. J. Agric. 14, 105.

Jespersen, J. and Olsen, H. M. (1939). Bevetn. Lab. landokon. Forsøk., Kbh., no. 186.

Jespersen, J. and Olsen, N. J. H. (1939). Beretn. Lab. landokon. Forsak., Kbh., no. 182 .

McFarlane, W. D., Fulmer; H. L. and Jukes, T. H. (1930). Biochem. J. 24, 1611.

Ministry of Agriculture and Fisheries (1938). Report of the Poultry Technical Committee for Great Britain. H.M.S.O.

\section{Statistics of Infant Mortality}

Dr. I. Leitch (Rowett Research Institute, Bucksburn, Aberdeen)

The statistical material to be presented is, in broad outline, a comparison of Scotland with other countries. Table 1 shows that infant

TABLE 1

INFANT MORTALITy RATE PER 1000 LIVE BiRTHS IN

SCotland Compared with other Countries, 1934-1938

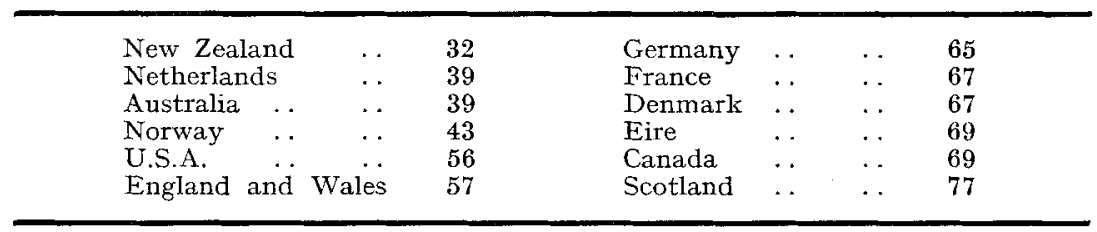

mortality in Scotland is high compared with that in England and Wales, Eire, the Dominions, the United States and several European countries. It is, in fact, higher than in any country of Western Europe except Spain and Portugal.

Table 2 shows that Scotland has not always been so unfavourably placed. At the end of last century, infant mortality in Scotland was lower than in England and Wales and other countries, e.g., the Netherlands, which have since greatly improved their position. 
TABLE 2

Infant Mortality: Historical Review

\begin{tabular}{ccc|c|c}
\hline & & & Scotland & England and Wales \\
$1856-1860$ & $\ldots$ &.. & 120 & 152 \\
$1881-1890$ & $\ldots$ &.. & 119 & 142 \\
$1911-1920$ & $\ldots$ &.. & 106 & 100 \\
$1936-1938$ &. &.. & 77 & 56 \\
\hline
\end{tabular}

It is well recognized that infant mortality is less in rural areas than in cities and this is true of Scotland, but even the rural rates in Scotland (Table 3) are higher than those in many large cities elsewhere. The rates in Scottish cities are excessively high.

TABLE 3

Infant Mortality: Geographical Distribution, 1938

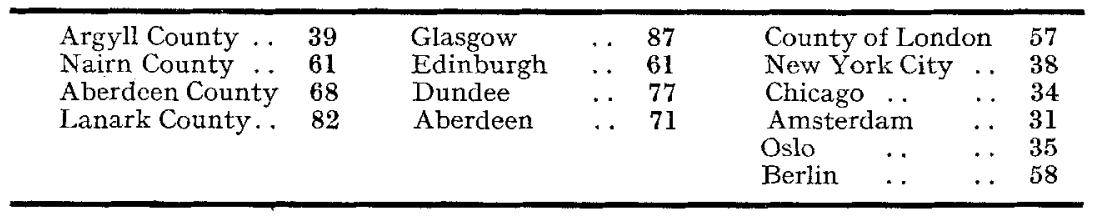

In face of this depressing picture, the first question is whether an analysis of the causes of death throws any light on the reasons for the excess mortality in Scotland. Table 4 shows that the great reductions in infant mortality that have been made, for instance, in England and Wales and New Zealand, are due mainly to reduction of deaths from infective disease and that the excess in Scotland is due chiefly to the persistently high death rate from infections.

TABLE 4

Ingant Mortality from Principal Causes PER 1000 Live Births

\begin{tabular}{|c|c|c|c|c|c|c|c|c|c|}
\hline & $\begin{array}{c}\text { Epi- } \\
\text { demic } \\
\text { diseases }\end{array}$ & $\begin{array}{l}\text { Tuber- } \\
\text { culosis }\end{array}$ & $\begin{array}{l}\text { Respi- } \\
\text { ratory } \\
\text { diseases }\end{array}$ & $\mid \begin{array}{c}\text { Gastro- } \\
\text { intest- } \\
\text { inal } \\
\text { diseases }\end{array}$ & $\begin{array}{l}\text { Con- } \\
\text { vul- } \\
\text { sions }\end{array}$ & $\begin{array}{c}\text { Mal- } \\
\text { forma- } \\
\text { tions }\end{array}$ & $\begin{array}{c}\text { Early } \\
\text { in- } \\
\text { fancy } \\
\text { deaths }\end{array}$ & $\begin{array}{l}\text { Other } \\
\text { causes }\end{array}$ & Total \\
\hline New Zealand & & & & & & & & & \\
\hline $1902-1906 \ldots$ & $5 \cdot 5$ & $1 \cdot 5$ & $9 \cdot 7$ & $15 \cdot 3$ & $4 \cdot 1$ & $1 \cdot 3$ & $27 \cdot 6$ & $7 \cdot 9$ & $72 \cdot 9$ \\
\hline $1922-1926 \ldots$ & $1 \cdot 8$ & $0 \cdot 4$ & $4 \cdot 3$ & $2 \cdot 8$ & $1 \cdot 3$ & $4 \cdot 8$ & $22 \cdot 4$ & $3 \cdot 3$ & $41 \cdot 1$ \\
\hline $1937-1939 \ldots$ & $1 \cdot 0$ & $0 \cdot 2$ & $3 \cdot 4$ & $1 \cdot 2$ & 0.2 & $5 \cdot 9$ & $17 \cdot 8$ & $3 \cdot 0$ & $32 \cdot 7$ \\
\hline $\begin{array}{r}\text { England and } \\
\text { Wales }\end{array}$ & & & & & & & & & \\
\hline $1923-1927$. & $6 \cdot 5$ & $1 \cdot 3$ & $16 \cdot 0$ & $8 \cdot 4$ & $3 \cdot 8$ & $4 \cdot 4$ & $27 \cdot 8$ & $3 \cdot 7$ & $71 \cdot 9$ \\
\hline 1938 & $2 \cdot 5$ & $0 \cdot 6$ & $9 \cdot 6$ & $5 \cdot 7$ & $1 \cdot 2$ & $6 \cdot 0$ & $23 \cdot 2$ & $3 \cdot 9$ & $52 \cdot 7$ \\
\hline Scotland & & & & & & & & & \\
\hline $1922-1930$ & $10 \cdot 9$ & $1 \cdot 9$ & $20 \cdot 5$ & $8 \cdot 1$ & $3 \cdot 4$ & $4 \cdot 5$ & $33 \cdot 8$ & $5 \cdot 5$ & $88 \cdot 6$ \\
\hline 1933 & $7 \cdot 5$ & $1 \cdot 2$ & $16 \cdot 7$ & $9 \cdot 8$ & $2 \cdot 5$ & $5 \cdot 5$ & $33 \cdot 2$ & $4 \cdot 7$ & $81 \cdot 1$ \\
\hline 1937 & $7 \cdot 0$ & $1 \cdot 0$ & $18 \cdot 1$ & $9 \cdot 3$ & $1 \cdot 7$ & $6 \cdot 4$ & $31 \cdot 8$ & $5 \cdot 0$ & $80 \cdot 3$ \\
\hline
\end{tabular}

A high infant mortality rate is correlated, both within countries and when countries are compared, with poverty, unemployment and bad voL. 1,1944$]$ 
housing. The proportion of people living in poverty in Scotland is twice as high as in England and Wales and that proportion includes a very high percentage of all young children. The percentage of overcrowding in Scotland is six times that in England and Wales and the condition of the houses in many Scottish rural areas, as well as city slums, is very bad. It is obvious that the chances of survival of infants born in poverty, into overcrowded and insanitary houses, cannot be high.

On the other hand, to judge from the experience of successful countries, the mortality from infective disease, which falls with increasing weight on infants between 1 and 12 months of age, is relatively easily reduced. There is no doubt that attention to housing combined with improvement of infant feeding would produce quick and dramatic results. It appears to be more difficult to reduce the first month component of infant mortality and the loss due to stillbirth. These two are, without doubt, apart from obstetric mishaps, referable to the same or similar causes, closely associated with the health of the mother during pregnancy. Table 5 shows that the Scottish position is bad, although the excess mortality is relatively less than that at later ages. It is unlikely that the excess should be due, to any great degree, to poor obstetrics. It is in accordance with the high incidenee of poverty, unemployment and their attendant evils in Scotland to suppose that much of it is due to maternal malnutrition.

TABLE 5

Stillbirths and Neonatal Deaths.

PER 1000 TOTAL BIRThS

\begin{tabular}{cc|c|c|c} 
& & Stillbirths & Neonatal deaths & Total \\
\hline New Zealand & & & & \\
1935 &. & $29 \cdot 9$ & $21 \cdot 4$ & $51 \cdot 3$ \\
1936 &. & $28 \cdot 6$ & $21 \cdot 7$ & $50 \cdot 3$ \\
1937 &. & $28 \cdot 4$ & $21 \cdot 6$ & $50 \cdot 0$ \\
1938 &. & $26 \cdot 5$ & $23 \cdot 5$ & $50 \cdot 0$ \\
1939 &. & $30 \cdot 3$ & $21 \cdot 2$ & - \\
1940 &. & $28 \cdot 6$ & - & - \\
1941 &. & $26 \cdot 9$ & - & \\
England and Wales & & & \\
1935 &. & $40 \cdot 7$ & $29 \cdot 1$ & $68 \cdot 8$ \\
1936 &. & $39 \cdot 7$ & $29 \cdot 0$ & $67 \cdot 6$ \\
1937 &. & $39 \cdot 0$ & $28 \cdot 6$ & $65 \cdot 5$ \\
1938 &. & $38 \cdot 3$ & $27 \cdot 2$ & $64 \cdot 8$ \\
1939 & $\therefore$ & $37 \cdot 8$ & $27 \cdot 0$ & $63 \cdot 9$ \\
1940 &. & $36 \cdot 1$ & $27 \cdot 8$ & -9 \\
1941 &. & $34 \cdot 4$ & $27 \cdot 5$ & \\
1942 &. & $33 \cdot 0$ & - & $77 \cdot 2$ \\
Scotland &. & $42 \cdot 2$ & $35 \cdot 0$ & $77 \cdot 9$ \\
1939 &. & $42 \cdot 1$ & $35 \cdot 7$ & - \\
1940 &. & $39 \cdot 5$ & - & \\
1941 &. & $38 \cdot 1$ & & \\
1942 &. & & &
\end{tabular}

